\title{
Connectivism: A Review
}

\section{Mina Khatibi ${ }^{1}$, Mahboobeh Fouladchang ${ }^{2}$}

\section{ABSTRACT}

George Siemens and Stephen Downes developed a theory for the digital age, called connectivism, denouncing boundaries of behaviorism, cognitivism, and constructivism. Connectivism is the thesis that knowledge is distributed across a network of connections, and therefore that learning consists of the ability to construct and traverse those networks. An account of connectivism is therefore necessarily preceded by an account of networks. Current developments with technology and social software are significantly altering: (a) how learners access information and knowledge, and (b) how learners dialogue with the instructor and each other. Both of these domains (access and interaction) have previously been largely under the control of the teacher or instructor.

Since half of what is known today was not known 10 years ago, there should be more researches about the use, benefits and drawbacks of connectivism in the cotext of formal and informal lerning. Although there is not a large amount of research currently available on the application of connectivism in education, some possible applications, such as: social networking, personal learning environments and open courseware are explained.

Keywords: Connectivism

${ }^{1} \mathrm{PhD}$ Student, Department of Educational Psychology, Shiraz University, Dubai, UAE

${ }^{2}$ Professor of Educational Psychology, Shiraz University, Shiraz, Iran 


\section{Connectivism: A Review}

For many years educators and researchers have examined the topic of how people learn. Several widely accepted learning theories have developed over the last hundred years. But do students learn the same way today as they did 100 years ago? Has technology changed the way our brain process and connects information? Do the students of today learn new information more efficiently than their teachers? George Siemens thinks so. Siemens has developed an emerging learning theory he called "connectivism" which addresses how learners in the digital-age process and retain new information (Elliot and Martin, 2011).

George Siemens coined the term 'connectivism' to describe learning networks (Siemens, 2005). Connectivism is the thesis that knowledge is distributed across a network of connections, and therefore that learning consists of the ability to construct and traverse those networks. An account of connectivism is therefore necessarily preceded by an account of networks ( Downes, 2012).

Behaviorism, cognitivism, and constructivism are the three broad learning theories most often utilized in the creation of instructional environments. These theories, however, were developed in a time when learning was not impacted through technology. Over the last twenty years, technology has reorganized how we live, how we communicate, and how we learn. Learning needs and theories that describe learning principles and processes should be reflective of underlying social environments (Siemens, 2005).

Knowledge is literally the set of connections between entities. In humans, this knowledge consists of connections between neurons. In societies, this knowledge consists of connections between humans and their artifacts. Learning is the creation and removal of connections between the entities, or the adjustment of the strengths of those connections. A learning theory is, literally, a theory describing how these connections are created or adjusted ( Downes, 2012).

Connectivism is driven by the understanding that decisions are based on rapidly altering foundations. New information is continually being acquired. The ability to draw distinctions between important and unimportant information is vital. The ability to recognize when new information alters the landscape based on decisions made yesterday is also critical (Siemens, 2005).

Concern runs high about the ability of today's education system to meet the growing challenges of global competition (Siemens, 2008). A recent report by National Center on Education and the Economy (2007) states "that our education and training systems were built for another era". Jenkins, Healey, and Zetter (2007) suggest a reformulation of universities is required to address issues of "super complexity". Dede, Korte, Nelson, Valdez, and Ward (2005) place a similar emphasis on education as one of "two keystones of advancing prosperity and quality of life" the other being investment in information technologies( Siemens, 2008). 


\section{Connectivism: A Review}

The call for academic reform, driven by growing fears of lack of competitiveness and innovation in a global economy, has reached an almost fevered pitch. Schrag (2007) suggests a key problem is American society's illogical perception of expecting "schools to solve every cultural and economic problem".

Vaill (1996) emphasizes that "learning must be a way of being - an ongoing set of attitudes and actions by individuals and groups that they employ to try to keep abreast the surprising, novel, messy, obtrusive, and recurring event.

Today, these foundational principles have been altered. Knowledge is growing exponentially. In many fields the life of knowledge is now measured in months and years. Gonzalez (2004) describes the challenges of rapidly diminishing knowledge life:

"One of the most persuasive factors is the shrinking half-life of knowledge. The "half-life of knowledge" is the time span from when knowledge is gained to when it becomes obsolete. Half of what is known today was not known 10 years ago. The amount of knowledge in the world has doubled in the past 10 years and is doubling every 18 months according to the American Society of Training and Documentation (ASTD). To combat the shrinking half-life of knowledge, organizations have been forced to develop new methods of deploying instruction."

\section{Some significant trends in learning:}

Many learners will move into a variety of different, possibly unrelated fields over the course of their lifetime.

Informal learning is a significant aspect of our learning experience. Formal education no longer comprises the majority of our learning. Learning now occurs in a variety of ways - through communities of practice, personal networks, and through completion of work-related tasks.

Learning is a continual process, lasting for a lifetime. Learning and work related activities are no longer separate. In many situations, they are the same.

Technology is altering (rewiring) our brains. The tools we use define and shape our thinking. The organization and the individual are both learning organisms. Increased attention to knowledge management highlights the need for a theory that attempts to explain the link between individual and organizational learning (Downes, 2012).

It is a clear fact that nowadays knowledge is growing faster than ever before and the official and private organizations using knowledge, especially educators and employers, spend a significant amount of time on continuing education programs for students or employees as taking classes is not enough because the traditional ways are not able to keep the pace with a changing knowledge and work environment. Lately, with the spreading of information and communication technology, the dream of network learning has become a reality, at least technically, and now a 
vast amount of spontaneous knowledge exchange is taking place through information and communication technology (Shahin, 2012).

But what becomes of the teacher? How do the practices of the educator change in networked environments, where information is readily accessible? How do we design learning when learners may adopt multiple paths and approaches to content and curriculum? How can we achieve centralized learning aims in decentralized environments( Siemens, 2008)?

\section{BACKGROUND}

Driscoll (2000) defines learning as "a persisting change in human performance or performance potential which must come about as a result of the learner's experience and interaction with the world". This definition encompasses many of the attributes commonly associated with behaviorism, cognitivism, and constructivism - namely, learning as a lasting changed state (emotional, mental, physiological (i.e. skills)) brought about as a result of experiences and interactions with content or other people.

Gredler (2001) expresses behaviorism as being comprised of several theories that make three assumptions about learning:

1. Observable behavior is more important than understanding internal activities.

2. Behavior should be focused on simple elements: specific stimuli and responses.

3. Learning is about behavior change.

\section{Limitations of Behaviorism, Cognitivism, and Constructivism}

A central tenet of most learning theories is that learning occurs inside a person. Even social constructivist views, which hold that learning is a socially enacted process, promotes the principality of the individual (and her/his physical presence - i.e. brain-based) in learning. These theories do not address learning that occurs outside of people (i.e. learning that is stored and manipulated by technology). They also fail to describe how learning happens within organizations (Siemens, 2005).

Learning theories are concerned with the actual process of learning, not with the value of what is being learned. In a networked world, the very manner of information that we acquire is worth exploring. The need to evaluate the worthiness of learning something is a meta-skill that is applied before learning itself begins (Siemens, 2005).

Some questions to explore in relation to learning theories and the impact of technology and new sciences (chaos and networks) on learning:

- How are learning theories impacted when knowledge is no longer acquired in the linear manner? 
- What adjustments need to made with learning theories when technology performs many of the cognitive operations previously performed by learners (information storage and retrieval)?

- How can we continue to stay current in a rapidly evolving information ecology?

- How do learning theories address moments where performance is needed in the absence of complete understanding?

- What is the impact of networks and complexity theories on learning?

- What is the impact of chaos as a complex pattern recognition process on learning?

- With increased recognition of interconnections in differing fields of knowledge, how are systems and ecology theories perceived in light of learning tasks (Siemens, 2005)?

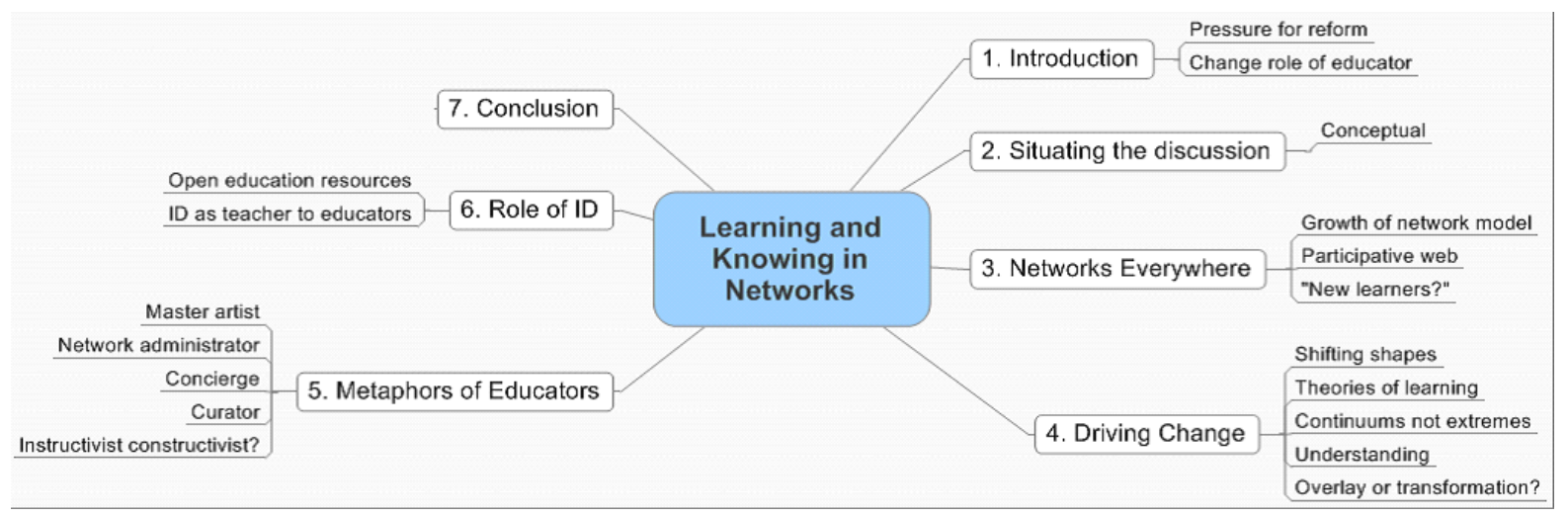

\section{DISCUSSION}

This review is intended to foster discussion on the role of an educator in a world increasingly defined by networked structure. While the body of research builds in how networks function and how information flows in networks, the attention given to the specific roles of educator and instructional designer has not received much attention. As such, thoughts expressed here are best seen at the conceptual level of this simple taxonomy( Siemens, 2008):

1. Conceptualization - exploration of theories, ideas, concepts, brainstorming, and questioning the boundaries of what currently exists.

2. Experimentation - narrowing the focus of the outcomes of the conceptual stage, the formation of a research focus, and the active experimentation and evaluation of different ideas and approaches.

3. Implementation - broad scale adoption based on previous two levels, emphasizing the understanding gained through experimentation.

Our focus here is on the conceptual level, with the intent of exploring how many of the most significant changes within society today might influence or change the role of educators and, as a consequence, the role of instructional designers. 


\section{Theories of Learning}

These are shown in Table 1.

Table 1. Learning Theories

\begin{tabular}{|c|c|c|c|c|}
\hline Property & Behaviourism & Cognitivism & Constructivism & Connectivism \\
\hline $\begin{array}{l}\text { How learning } \\
\text { occurs }\end{array}$ & $\begin{array}{l}\text { Black box- } \\
\text { observable } \\
\text { behaviour main } \\
\text { focus }\end{array}$ & $\begin{array}{l}\text { Structured, } \\
\text { computational }\end{array}$ & $\begin{array}{l}\text { Social, meaning } \\
\text { created by each } \\
\text { learner } \\
\text { (personal) }\end{array}$ & $\begin{array}{l}\text { Distributed } \\
\text { within a } \\
\text { network, social, } \\
\text { technologically } \\
\text { enhanced, } \\
\text { recognizing and } \\
\text { interpreting } \\
\text { patterns }\end{array}$ \\
\hline $\begin{array}{l}\text { Influencing } \\
\text { factors }\end{array}$ & $\begin{array}{l}\text { Nature of } \\
\text { reward, } \\
\text { punishment, } \\
\text { stimuli }\end{array}$ & $\begin{array}{l}\text { Existing schema, } \\
\text { previous } \\
\text { experiences }\end{array}$ & $\begin{array}{l}\text { Engagement, } \\
\text { participation, } \\
\text { social, cultural }\end{array}$ & $\begin{array}{l}\text { Diversity of } \\
\text { network, } \\
\text { strength of ties }\end{array}$ \\
\hline Role of memory & $\begin{array}{l}\text { Memory is the } \\
\text { hardwiring of } \\
\text { repeated } \\
\text { experiences- } \\
\text { where reward } \\
\text { and punishment } \\
\text { are most } \\
\text { influential }\end{array}$ & $\begin{array}{l}\text { Encoding, } \\
\text { storage, retrieval }\end{array}$ & $\begin{array}{l}\text { Prior knowledge } \\
\text { remixed to } \\
\text { current context }\end{array}$ & $\begin{array}{l}\text { Adaptive } \\
\text { patterns, } \\
\text { representative of } \\
\text { current state, } \\
\text { existing in } \\
\text { networks }\end{array}$ \\
\hline $\begin{array}{l}\text { How transfer } \\
\text { occurs }\end{array}$ & $\begin{array}{l}\text { Stimulus, } \\
\text { response }\end{array}$ & $\begin{array}{l}\text { Duplicating } \\
\text { knowledge } \\
\text { constructs of } \\
\text { "knower" }\end{array}$ & Socialization & $\begin{array}{l}\text { Connecting to } \\
\text { (adding) nodes }\end{array}$ \\
\hline $\begin{array}{l}\text { Types of learning } \\
\text { best explained }\end{array}$ & $\begin{array}{l}\text { Task-based } \\
\text { learning }\end{array}$ & $\begin{array}{l}\text { Reasoning, clear } \\
\text { objectives, } \\
\text { problem solving }\end{array}$ & $\begin{array}{l}\text { Social, vague } \\
\text { ("ill defined") }\end{array}$ & $\begin{array}{l}\text { Complex } \\
\text { learning, rapid } \\
\text { changing core, } \\
\text { diverse } \\
\text { knowledge } \\
\text { sources }\end{array}$ \\
\hline
\end{tabular}

As theories of learning share many attributes and new ones build progressively on previous ones, any consideration of learning requires a review of existing theories. Driscoll (2000) categorizes learning into three broad epistemological frameworks: 


\section{Connectivism: A Review}

- Objectivism states that reality is external and objective, and that knowledge is gained through experiences.

- Pragmatism states that reality is provisional, and knowledge is negotiated through experience and thinking.

- Interpretivism states that reality is internal, and knowledge is constructed.

These epistemologies in turn form the foundation of the most common theories of learning:

1. Behaviorism, which asserts that learning is a "black box" activity, in that we do not know what occurs inside the learner, focuses its efforts on managing external, observable behaviors, and finds much of its existence in objectivism.

2. Cognitivism, which spans a continuum from learning as information processing (a computer model) at one end, to learning as reasoning and thinking on the other, finds much of its identity in pragmatism (Siemens, 2008).

3. Constructivism, which covers a broad spectrum of research overlapping with cognitivism, contends that learning involves each individual learner making sense and constructing knowledge within his or her own context; it finds its foundation in interpretive.

To the three-fold view of epistemology, Downes (2006) adds a fourth: the view of knowledge as composed of connections and networked entities. The concept of emergent, connected, and adaptive knowledge provides the epistemological framework for connectivism (Siemens, 2005) as a learning theory. Connectivism posits that knowledge is distributed across networks and the act of learning is largely one of forming a diverse network of connections and recognizing attendant patterns (Siemens, 2006). As Cronon (1998) states, "More than anything else, being an educated person means being able to see connections so as to be able to make sense of the world and act within it in creative ways."

Mergel's (1998) emphasis on Ertmer's and Newby's “five definitive questions ... to distinguish learning theory" (Distinguishing One Learning section) provides a framework to organize the above cited theories:

1. How does learning occur?

2. What factors influence learning?

3. What is the role of memory?

4. How does transfer occur?

5 . What types of learning are best explained by this theory?

Table 1 indicates how different theories of learning relate based on Ertmer's and Newby's questions (Siemens, 2008). 


\section{HISTORY}

Connectivism was introduced in 2005 by two publications, Siemens' Connectivism: Learning as Network Creation (2005) and Downes' An Introduction to Connective Knowledge ( Downes, 2012). Both works received significant attention and an extended discourse has followed on the appropriateness of connectivism as a learning theory for the digital age. In 2007 Kerr entered into the debate with a series of lectures and talks on the matter, as did Forster, both at the Online Connectivism Conference at the University of Manitoba (2007). In 2008, in the context of digital and e-learning, connectivism was reconsidered and its technological implications were discussed by Siemens' and Ally (2008).

\section{PRINCIPLES}

- Principles of connectivism(Siemens, 2005):

- Learning and knowledge rests in diversity of opinions.

- Learning is a process of connecting specialized nodes or information sources.

- Learning may reside in non-human appliances.

- Nurturing and maintaining connections is needed to facilitate continual learning.

- Ability to see connections between fields, ideas, and concepts is a core skill.

- Currency (accurate, up-to-date knowledge) is the intent of all connectivist learning activities.

- Decision-making is itself a learning process. Choosing what to learn and the meaning of incoming information is seen through the lens of a shifting reality. While there is a right answer now, it may be wrong tomorrow due to alterations in the information climate affecting the decision (Siemens, 2005).

\section{DISTINCTIVENESS}

- Existing theories of learning fail to account for the expansion and creation of knowledge.

- Connectivism and networked learning, on the other hand, suggest a continual expansion of knowledge.

- The primacy of the connection - all other forms of learning flow from an initial connection to something - a person, a concept, and idea.

- Growth in abundance and complexity of knowledge.

- Technology. Looking to our history reveals the prominence of technology in opening new doors - form writing to air travel. Technology is an enabler of new opportunities.

- Connectivism brings together concepts from different domains in a novel way. It is rare to have a singularly unique idea. Even existing theories - behaviorism, constructivism, and cognitivism, do not stand as fully complete and original ideas (Wikiversity, 2012).

\section{CRITICISM}

The notion of a "new" theory for learning based on network structures, complex changing environments, and distributed cognition has drawn criticismVerhagen (2006), in his critique of 


\section{Connectivism: A Review}

connectivism, specifically argues for the ineffectiveness of a theory based on "unsubstantiated philosophising" . Kerr (2007) postulates that connectivism is an unnecessary theory, for in his opinion, existing theories satisfactorily address the needs of learning in today's technologically, connected age. An argument appealing to popularity, however, is not a real basis for declaring something a "new learning theory".

\section{IMPLICATIONS}

The notion of connectivism has implications in all aspects of life. This review largely focuses on its impact on learning, but the following aspects are also impacted: Management and leadership. The management and marshalling of resources to achieve desired outcomes is a significant challenge. Realizing that complete knowledge cannot exist in the mind of one person requires a different approach to creating an overview of the situation.

Speed of "idea to implementation" is also improved in a systems view of learning. Media, news, information. This trend is well under way. Mainstream media organizations are being challenged by the open, real-time, two-way information flow of blogging(Siemens, 2005).

\section{CONCLUSION}

Connectivism presents a model of learning that acknowledges the tectonic shifts in society where learning is no longer an internal, individualistic activity. How people work and function is altered when new tools are utilized. The field of education has been slow to recognize both the impact of new learning tools and the environmental changes in what it means to learn. Connectivism provides insight into learning skills and tasks needed for learners to flourish in a digital era(Siemens, 2005).

\section{REFERENCES}

Cronon W, (1998). Qualities of a liberally educated person.Retrieved January 10, 2008, from http://www.aacu.org/issues/liberaleducation/cronon.cfm.

Dede C, Korte S, Nelson R, Valdez G, Ward D J, (2005). Transforming learning for the 21st century: An economic imperative. Retrieved January 10, 2008, from http://www.learningpt.org/tech/transforming.pdf.

Downes S, (2006). Learning networks and connective knowledge.Retrieved on January 10, 2008, from http://it.coe.uga.edu/itforum/paper92/paper92.htm.

Downes S, (2012). Connectivism and Connective Knowledge Essays on meaning and learning networks, ISBN: 978-1-105-77846-9. 
Downes S, (2005). The Living Arts: The Future of Learning Online. Moncton: Stephen Downes. Retrieved May 30, 2005 from http://www.downes.ca/files/guelph.ppt.

Driscoll M, (2000). Psychology of Learning for Instruction.Needham Heights, MA, Allyn\& Bacon.

Duke B, Harper G, Johnston M, (2013).Connectivism as a digital age learning theory. The International HETL Review, special issue, pp 1-13.

Elliot R and Martin S, (2011).Connectivism's role as a learning theory and its application in the classroom.Boise State University, EDTECH, 504.

Ertmer PA, Newby TJ, (1993). Behaviorism, cognitivism, constructivism: Comparing critical features from an instructional design perspective. Performance Improvement Quarterly, 6 (4): 50-70.

Gonzalez C, (2004). The Role of Blended Learning in the World of Technology.Retrieved December10, 2004 from http://www.unt.edu/benchmarks/archives/2004/september04/eis.htm.

Gredler ME, (2005). Learning and Instruction: Theory into Practice - 5th Edition, Upper Saddle River, NJ, Pearson Education.

Jenkins A, Healey M, Zetter R, (2007). Linking teaching and research in disciplines and departments. Retrieved January 10, 2008, from Higher Education Academy Web site: http://www.heacademy.ac.uk/assets/York/documents/LinkingTeachingAndResearch_Apri 107.pdf.

Kerr B, (2007, February). A challenge to connectivism. Paper presented at Online Connectivism Conference. Retrieved January 10, 2008,https://sas.elluminate.com/site/external/jwsdetect/playback.jnlp?psid=2007-02-07.11 07.M.1CB9A5466ACA919ADFB409D4128ABC.vcr.

Mergel B, (1998). Instructional design and learning theories. Retrieved January 10, 2008, from University of Saskatchewan, College of Education Web site: http://www.usask.ca/education/coursework/802papers/mergel/brenda.htm.

Schrag P, (2007, September). Schoolhouse crock: Fifty years of blaming America's educational system for our stupidity. Harpers Magazine, 36-44.

Shahin M, (2012). Pros and cons of connectivism as a learning theory.IJPSS, vol. 2; 4: 437-454.

Siemens G, (2005). Connectivism: A learning theory for a digital age. International Journal of Instructional Technology and Distance Learning, 2(1).Retrieved January 10, 2008, from http://www.itdl.org/Journal/Jan_05/article01.htm. 
Siemens G, (2006). Knowing knowledge.Retrieved from www.knowingknowledge.com.

Siemens G, (2008). Learning and Knowing in Networks: Changing roles for Educators and Designers Presented to ITFORUM for Discussion, January 27, pp 1-26.

Siemens G, (2009). Elearnspace.Retrieved from http://www.elearnspace.org/blog/8.

University of Manitoba, (2007).Online connectivism conference.Retrieved January 10, 2008, from http://www.umanitoba.ca/learning_technologies/connectivisim/.

Vaill PB, (1996). Learning as a Way of Being. San Francisco, CA, Jossey-Blass Inc.

Verhagen P, (2006). Connectivism: A new learning theory? Retrieved January 10, 2008, from,http://elearning.surf.nl/e-learning/english/3793. 